\title{
WAGE PAYMENTS IN THE WORLD
}

\author{
Anzhelika Mashevska'
}

\begin{abstract}
The purpose of the article is to analyze earnings in different countries of the world. The wages of the population of different countries are analyzed: the USA, Canada, the former Soviet Union countries, the rating of 30 states-leaders on average salary (gross) is made. It is proved that, in addition to national statistical institutions, international organizations are also engaged in the compilation of wage ratings. Their statistical surveys are highly reliable: when calculating the average wage, salaries of employees are taken into account, emphasizing their qualifications and work experience, without taking into account businesspersons, private or individual entrepreneurs, pensioners, assisted persons and others. Method. According to the ratings, the list of the most sought after and highly profitable professions is constantly changing. The labor market is out of place, and before the prestigious specialties cease to be relevant, and their place is occupied by new ones, the demand of representatives of a profession also depends on the region. What has become of further development is that in recent years many popular and unusual professions have appeared in the countries of the Far East: Japan, Korea, China, Taiwan, Hong Kong and others. For example, many Ukrainian citizens teach English as a "native" language in China. It is important for the Chinese that the teacher be European, and the demand for language courses is enormous (especially in the province). Results. For those citizens who have pronounced Caucasian features, they have blond hair, fair complexion, and eyes that are beautiful and young, with even greater opportunities to earn money, the trend for the European appearance in China, Korea and Japan is huge. Value/originality. According to the analysis of the countries with the highest average salary level, 20 positions belong to the European countries, 2 are from America and Oceania and 6 are Asian. The important products and services can have a serious impact on cost of living, with 100 USD being of different weight in Japan and in Ukraine. Therefore, the inflationary processes that enter the economy significantly affect the level of wages of people, which in turn affects the standard of living of the population.
\end{abstract}

Key words: salary, visa for the cordon, homeland, Union of Independent Powers, Europe, the USA, America, Canada, International Organization of Public Relations, Organization of Economic and Social Development - OECP, Trading Economics.

JEL Classification: J01, J31, J61, F01

\section{Introduction}

Salary, reduced wages (also wages and salaries, wage payments) are the remuneration, usually calculated in monetary terms, paid by the owner(s) under the employment contract to the employee or their authorized body for the work they have performed. The amount of salary depends on the complexity and conditions of work performed, professional and business qualities of the person, the results of work and economic activity of the enterprise. Women's salaries are on average one third lower than men's for the same job.

In terms of a market economy, wages are the price of labor in the labor market, the result of a voluntary agreement between the owner of the ability to work (the seller of labor, the representative of the household) and the firm (buyer of labor). Wages are included in the structure of Gross Domestic Product when calculating it by income (household income from the labor market); part of the enterprise's costs of remuneration.

The question of who, where and how much earns and, accordingly, what place in the world salary ranking is occupied by a country is quite relevant. In addition to cognitive interest, there is a more practical application of such knowledge. This is especially helpful for those who are considering going abroad for work or leaving the country for

Corresponding author:

${ }^{1}$ Vinnytsia National Agrarian University, Ukraine.

E-mail: angelikaam@ukr.net

ORCID: https://orcid.org/0000-0001-9514-504X

ResearcherID: L-5938-2018 
good. In this case, you need to know how different salaries are in the countries of the world, what you can expect and what professions are more in demand. You should also consider whether you can trust international salary ratings.

\section{Economic crisis effects on consumer behavior}

The purpose of the article is to analyze wages in the world. One of the most important concepts used to compile different rankings is the average monthly wage in a given country. At first glance, this value is easily determined by the simple arithmetic mean finding method. This method is still practiced in the CIS countries: to make an exhaustive list of professions and positions, to make monthly salaries on the list and to divide by the number of posts in the list. The biggest disadvantage of this method is that the result is far from the real state of things. Among the reasons for this there are the following: - summaries of salaries (with all allowances and bonuses) of ordinary employees (ordinary workers, janitors, dishwashers, etc.), and of staff (directors, top managers, etc.) are summed up. As a result, at a salary, for example, one worker receives in the amount of 200 USD and the other - 1000 average will be 600 USD;

- tax and other social payments and deductions in different countries of the world, which can vary from 10 to $40 \%$ depending on each case, are not taken into account;

- gender inequality - men get $10-20 \%$ more than women;

- no regional differentiation: capital / province, city / countryside. In most European countries (EU, EFTA), the USA, Canada (OECD) with high GDP, the determination of the average monthly wage is based on another principle, which allows a more adequate picture of the real situation with the size of wages. The required number is the amount of salaries of employees in the middle of the list. This is a kind of limit: half of the employees is higher, the other half is below.

This principle of determining the average wage is called the median. The name comes from the notion of the median in geometry. For example, a firm five employees with salaries of 3000 USD, 2000 USD, 1000 USD, 900 USD and 800 USD. The median size in this case will be 1000 USD.

The difference in the application of the median principle of presence. When drawing up international rankings, as a unit of reference, they usually use not the national currency but the dollar of Purchasing Power Parity or PPP. One such dollar is equivalent to the USD spent in the US.

It allows to determine the amount of goods and services available in the United States for the monthly salary received in a particular country, and to compare the price level in different countries.

\section{Differences in consumer spending haviour among age groups}

Compilation of annual ratings of average salaries, in addition to national statistical institutions dealing with international organizations:

- International Labor Organization - ILO;

- Organization for Economic Cooperation and Development - OECD;

- Trading Economics - TI;

- Eurostat;

- Current Population Survey (the USA) and others.

The statistics provided by these organizations are highly reliable: when calculating the average wage, salaries of employees are taken into account, emphasizing their qualifications and work experience. However, businesspersons, private or individual entrepreneurs, pensioners, unemployed persons, etc. are not included in the calculation.

The calculations use different time characteristics: earnings per hour, day, week, month, quarter, six months, year.

Until recently, the ILO has been at the forefront of statistical surveys of wage rates. However, in today's context, especially in advanced market economies with non-standard jobs, ILO statistics with a base salary base and its methodology for gathering information are quickly outdated and often do not show the real situation.

The EU Statistical Service - Eurostat - in its research expands and details the number of components, further analyzing one-off bonuses, stock options, gratuities, housing or transport allowances, commissions, etc., including in-kind payments: clothing, gym, providing an expensive car from a firm, kindergarten, etc. An analysis of statistics over the last 10 years shows that traditionally the highest average wages in the world are from the EU, the US, Canada, Australia, New Zealand, Japan, the Republic of Korea and some other countries.

In spite of the fact that the ILO's official website reports do not contain data on a number of countries, and some of the information is outdated or requires re-examination, they give an idea of where the highest average wages in the world labor market are recorded. 
Vol. 1, No. 1, 2020

Green, Blue \& Digital Economy Journal

Table 1

30 Country leaders on average payment (GROSS):

\begin{tabular}{|c|c|c|}
\hline State & $\begin{array}{c}\text { Level of average salary (in USD per SCP) } \\
\text { according to ILO (in the absence } \\
\text { of information - TI) }\end{array}$ & The level of average salary in local currency \\
\hline Switzerland & 6775 & $6540 \mathrm{CHF}$ \\
\hline Denmark & $6289(\mathrm{TI})$ & $40101 \mathrm{DKK}(\mathrm{TE})$ \\
\hline Iceland & $5616(\mathrm{TI})$ & 615,000 ISK (TE) \\
\hline Norway & 5438 & $44310 \mathrm{NOK}$ \\
\hline Germany & 4852 & 4149 EUR \\
\hline Luxembourg & 4139 & 3535 EUR \\
\hline Ireland & 3728 & 3188 EUR \\
\hline Belgium & 3601 & 3079 EUR \\
\hline Finland & 3572 & 3055 EUR \\
\hline Singapore & 3570 & 4892 SGD \\
\hline Sweden & 3527 & 31,400 SEK \\
\hline France & $3508(\mathrm{TI})$ & 2998 EUR (TE) \\
\hline Netherlands & 3498 & 2988 EUR \\
\hline Australia & 3479 & 4828 Australian Dollars (TI) \\
\hline Spain & 3324 & 2843 euros \\
\hline New Zealand & $3272(\mathrm{TI})$ & 4973 New Zealand Dollars (TI) \\
\hline USA & $3190(\mathrm{TI})$ & 3190 USD (TE) \\
\hline Austria & 3094 & 2646 EUR \\
\hline Republic of Korea & 3067 & $3446000 \mathrm{KRW}$ \\
\hline Canada & $3060(\mathrm{TI})$ & 3977 CAD (TI) \\
\hline United Kingdom & 2905 & 2208 GBP \\
\hline Israel & 2714 & 9,724 ILS \\
\hline Japan & 2712 & $304300 \mathrm{JPY}$ \\
\hline Italy & 2515 & 2151 EUR \\
\hline Cyprus & $2156(\mathrm{TI})$ & 1848 EUR (TE) \\
\hline Hong Kong & $2027(\mathrm{TI})$ & $15897 \mathrm{HKD}(\mathrm{TI})$ \\
\hline Slovenia & $1929(\mathrm{TI})$ & 1654 EUR (TE) \\
\hline Saudi Arabia & 1710 & 6413 SAR \\
\hline Taiwan & $1677(\mathrm{TI})$ & 51669 TWD (TE) \\
\hline Czech Republic & $1464(\mathrm{TI})$ & $31851 \mathrm{CZK}(\mathrm{TE})$ \\
\hline
\end{tabular}

As the table shows, most countries with the highest average wages are in Europe. In 14 of them the salary amounted to more than three thousand dollars, in three - more than two thousand. Average salaries of more than a thousand euros have been fixed not only in Slovenia and the Czech Republic, but also in Slovakia, Estonia, Portugal, Latvia, Romania and others. Macedonia closes the list (674 USD).

The average salary in the CIS countries looks much more modest. Top 5 Wage Leaders (USD):

- The RF-632;

- Belarus - 460;

- Kazakhstan - 432;

- Armenia - 383;

- Moldova - 351.

The list of the most sought after and highly profitable professions is constantly changing.
The labor market is not in place, and before that prestigious specialties cease to be relevant, and their place is replaced by new ones. The demand of representatives of a profession also depends on the region.

The top 10 payroll leaders look like this:

- in Switzerland, the highest demand is for highly qualified doctors, programmers, engineers, lawyers and accountants. Their monthly salary ranges from 8000 USD and above. Specialists with Swiss diplomas (EFZ certificate) and years of practical experience are especially appreciated;

- In Denmark, the situation is almost the same. Top executives, doctors, pharmacists, finance analysts, lawyers, engineers, builders, scientists, programmers, university and school teachers are appreciated. These specialist categories can expect a salary of 6000 EUR a month and above; 
- Iceland is an island nation, so fisheries professionals, sailors and biotechnologists are always in demand. Highly valued are IT specialists, doctors, translators;

- There is a constant shortage of oil workers, IT specialists, doctors, police, pilots, electrical engineers, lawyers, financial analysts in Norway. Representatives of these professions earn from 6 000 to 9000 EUR a month;

- Germany is experiencing a shortage of recycling specialists, pharmacists, air traffic controllers, pilots, physicians, programmers, technical designers, insurers. The average monthly salaries in these areas start from 6000 EUR;

- in Ireland, among the most sought after specialties are lawyers, programmers, accountants, marketers; - Belgium is prepared to pay high salaries for lawyers, programmers, physicians, economics engineers;

- In Luxembourg, such highly paid fields as IT, transport, logistics, finance, insurance, pedagogy are open to Ukrainians;

- in Finland, the highest paid specialists are physicians. Programmers, chemists, engineers, economists, educators, environmentalists are also appreciated;

- Singapore is particularly attractive to IT professionals, economists, engineers, architects.

The salary of representatives of these professions is influenced by the presence of work experience, high qualification, knowledge of the language of the host country.

The lowest wage countries

The ranking of minimum wages in the world is headed by representatives of the African continent.

Table 2

\section{Countries with the lowest average wages} in the world

\begin{tabular}{|l|c|c|}
\hline \multicolumn{1}{|c|}{ State } & $\begin{array}{c}\text { Average salary } \\
\text { in USD }\end{array}$ & $\begin{array}{c}\text { The level of } \\
\text { average salary in } \\
\text { local currency }\end{array}$ \\
\hline Zimbabwe & 21 & $7600 \mathrm{ZWL}$ \\
\hline Malawi & 30 & $21827 \mathrm{MWK}$ \\
\hline Equatorial Guinea & 30 & $16838 \mathrm{XAF}$ \\
\hline Cape Verde & 39 & $3686 \mathrm{CVE}$ \\
\hline Ethiopia & 47 & $1309 \mathrm{ETB}$ \\
\hline $\begin{array}{l}\text { Democratic Republic } \\
\text { of the Congo }\end{array}$ & 55 & $90758 \mathrm{CDF}$ \\
\hline
\end{tabular}

- On the American continent, "leadership" belongs to Venezuela. After a threefold increase, the average salary here is 5196,000 Bolivar Fuerte or 21 USD.
- Among the CIS countries, the lowest average wages in Turkmenistan are 320 USD, Uzbekistan - 235 USD, Kyrgyzstan - 220 USD. The lowest wages are in Ukraine (168 USD) and Tajikistan (110 USD);

- In most countries, weekly rather than monthly wages are practiced;

- Different time costs. To earn an average wage in France, it will take 35 hours, the Russian Federation, Japan, the United States - 40 hours, in Vietnam, Kenya and others - up to 55 hours per week;

- Low salaries in many countries are not equivalent to low purchasing power, as well as vice versa. That is, low prices for products, clothing, services can overcompensate for low wages;

- Different length of vacation. If in Ukraine the holiday is 24 calendar days a year (excluding national and religious holidays), in Japan - only 10 days, in Singapore - a week, and in Denmark 30 days;

- gender inequality. In the vast majority of cases, women are paid less than men for work with men equal. For example, in Germany the difference can be up to $600 \mathrm{EUR}$;

- lump sum payments and bonuses - winter and summer, housing, food, medical and cultural needs; - In developed countries there is a clear tendency to reduce the differentiation of tariffs and rates. That is, the remuneration of low-skilled workers is only 2-3 times less than that of high-skilled workers. For example, in Japan this ratio is 1:4, in Sweden - 1: 3 . At the same time, special bonuses, etc. are paid for the qualification;

- Gross and net salaries. Most ratings indicate gross wages, that is, when the tax has not yet been paid. After all the necessary payments are made, the amount of salary can be reduced by $30-50$ percent or more.

The desire to make forces our compatriots to go to work in distant countries. There, citizens have to deal with unusual things for them, including in labor relations.

\section{Findings}

The multipolar world we live in is constantly changing: borders are being erased and people's mobility is increasing. Scientific and technological progress is not in place, bringing to us more and more new specialties and professions about which few have heard before.

In addition to the need for skilled engineers, physicians, programmers and representatives of 
other traditional professions, there is also a great need in the leisure industry for the developed world. For example, you need lego sculptors with salaries of up to 30000 USD a year or water slides in hourly paid water parks. In Western Europe, the USA, Japan, there is a great demand for designers, advertising and PR specialists.

The entertainment industry is experiencing a lack of gaming developers. Highly-paid IT professionals, computer graphic artists and artists can easily find a high-probability job here.

Today, anime, manga (for hentai lovers) fashion has spread all over the world, allowing Ukrainian artists to earn between $30000-40000$ USD a year. At the same time, citizens of Ukraine can work remotely and receive money from abroad by transferring to a card.

Ukrainians with a psychological or veterinary education will be able to earn up to 28000 USD as zoo psychologists, a need that is growing in the United States and European countries. The main responsibility of such professionals is to analyze the behavior of the pets and assist the owners in dealing with them.

Foreign nationals with Jewish roots (possibly in the fourth generation), including CIS citizens, were eligible to be employed in Israel under contract. In recent years, many sought-after unusual professions have appeared in countries in the Far East: Japan, Korea, China, Taiwan, Hong Kong, and others. For example, many Ukrainian citizens teach English as a "native" language in China. It is important for the Chinese that the teacher be European, and the demand for language courses is enormous (especially in the province). For those citizens who have pronounced Caucasian features, they have blond hair, fair complexion, and eyes that are beautiful and young, with even greater opportunities to earn money. Strange as it may seem, the fashion for European appearance in China, Korea and Japan is huge. Among the most sought after:

- models for exhibitions and presentations (girls and boys). Beginners can expect from 40-150 USD, experienced models up to 500-800 USD or more per day;

- artist-extras. In the film industry of China and Korea, it is believed that having a Europeanspeaking person in the film guarantees success, so the presence of the Europeans, at least as extras, is welcomed there;

- Fashion models of body parts - ears, nose, fingers, feet, etc. for advertising creams, earrings, bracelets, shoes. Wages of such models are up to 20 USD a day;

- model-dancers, musicians, DJs and more. Particularly appreciated are girls and boys with classical ballet education;

- presentation of a "foreign specialist" who allegedly works at a Chinese firm. This is an artistic role for men 30 and older presenting a fluent English. Earnings in USD - from 80 to 300 USD per day.

Among the unusual professions that are in demand today are those that have existed for thousands of years, for example, wizards on maps, gondoliers, carpenters and more. And a number of specialties have recently emerged: armpits (for the production of deodorants), toilet guides (show the way to tourists to the toilet), tasters of animal feed and more.

\section{Conclusions}

In economically developed countries there are some forms of remuneration and models of employee motivation for many decades. Western models differ in their diversity the role of the state in regulating the activity of the enterprise, the level of economy in the country, religious and national characteristics. Therefore, determining the importance of the category "Payment" is the need to study international experience to create modern accounting and retention accounting system with wages in Ukraine.

Wage payment is not only a major source of income, but also a determining a factor in the formation of social justice in society, solvency, which has a direct contribution to economic activity in the real sector of the national economic complex of the country.

Getting acquainted with international average wage rankings in the world is instructive and rewarding: comparing indicators will help you decide which countries are more likely to find high-paying jobs. The methodology developed by international organizations (ILO, Trading Economics (TI), Eurostat, etc.) allows you to obtain reliable data.

In the TOP-30 countries with the highest average wage level, 20 positions belong to the European countries, 2 to America and Oceania and 6 to Asian. When considering the data submitted, it should be borne in mind that the unit of measure is the dollar.

The wage / price ratio shows that the prices of the most important products and services can have a serious impact on the cost of living, with 100 USD being of different weight in Japan and Venezuela. 
Low wages in the CIS countries is a guarantee that labor emigration from these countries to Europe, America, and China will increase every year. This should be taken into account, in addition to the traditionally demanded specialties and professions, there are quite a few alternative ones lately, which give a chance to find a highpaying job.

\section{References:}

Charlotta Magnusson (2015). "Why Is There A Gender Wage Gap According To Occupational Prestige?" Acta Sociologica (Sage Publications, Ltd.) 53.2 (2010): 99-117. Academic Search Complete. Web. 26 Feb. 2015.

U.S. Bureau of Labor Statistics (2012). "Earnings of Women and Men by Race and Ethnicity, 2007". Accessed June 29, 2012.

"Employees" as a category excludes all those who are self-employed, and this statistics only considers workers over the age of 16. U.S. Department of Labor. Bureau of Labor Statistics (2013-02-26), Characteristics of Minimum Wage Workers: 2012.

Tennant, Michael (2014). "Minimum Wage The Ups \& Downs." New American (08856540) 30.12 (2014): 10-16.

Anzhelika Mashevska (2019). Formation of insurance company financial flows. Polish journal of science, no. 22, vol. 2, pp. 17-26.

Aleskerova, Yu., Mulyk, T., \& Fedoryshyna, L. (2018). Improving credit protection analysis methods Reports of main agricultural enterprises. Baltic Journal of Economic Studies, vol. 4, no. 2, pp. 1-7. doi: $10.30525 / 2256-0742 / 2018-4-2-1-7$

Aleskerova, Yu., \& Fedoryshyna, L. (2018). Analysis of investment activities of enterprises of Ukraine. Economic system development trends: the experience of countries of Eastern Europe and prospects of Ukraine.

Aleskerova, Yu., Fedoryshyna, L., \& Koval, N. (2018). Features of loan security for the reproduction of fixed assets for agricultural purposes. Baltic Journal of Economic Studies, vol. 4, no. 4, pp. 1-5. doi: 10.30525/2256-0742/2018-4-4-1-5

Aleskerova, Y., Kovalenko, L., \& Havryliuk, V. (2019). Innovative financial criteria for methodological approaches to the assessment of agrarian insurance. Baltic Journal of Economic Studies, vol. 5, no. 4, pp. 34-41. doi: 10.30525/2256-0742/2019-5-4-34-41

Todosiychuk, V. (2019). Public administration of anti-inflation policy in the system of monetary regulation of economy. Znanstvena misel journal. The journal is registered and published in Slovenia, vol. 2, no. 34, pp. 44-52.

Todosiychuk, V., \& Fedoryshyna, L. (2019). Analiz controlling financial risks of enterprise. Polish journal of science, no. 21, vol. 2, pp. 30-42. 